\author{
Oleg Skydan \\ Rector \\ Polissia National University, Zhytomyr \\ E-mail: skydanolegv@ukr.net \\ ORCID: 0000-0003-4673-9620

\section{Vadym Hrynyshyn} \\ External PhD student of the Department of Innovative Entrepreneurship and Investment Activities \\ Polissia National University, Zhytomyr \\ E-mail: luda2310@i.ua \\ ORCID: 0000-0002-3719-377X
}

\title{
Risks and threats to ensuring food security of Ukraine: methodological foundations and practical evaluation
}

\begin{abstract}
The article provides substantiation to the fact that ensuring food security of the state is an important component of its socioeconomic policy and a key indicator of the effectiveness of the national strategy in the local and global context. It has been proved that identification of risks and threats to food security in a timely manner makes it possible to assess the current trends of its main indicators and to further forecast them in a rapidly changing market environment. It has been identified and methodically supported that the system of risks and threats to food security is complementary related to the possibility of negative changes in its level, because the more likely the possibility of adverse changes, the higher the level of risk. It has been proved that the process of identifying food security risks should be based on the results of the analysis of the factors that cause them. Methodological steps in the context of risk assessment of the country in terms of the loss of food security have been identified: 1) systematization of food security indicators from the standpoint of risk management; 2) identification of all factors/threats that may cause adverse changes in indicators; 3 ) assessment of the possibility/probability of negative changes in food security indicators due to each of the identified factors/threats. The system of risks is determined from the standpoint of taking into account the sphere of formation and realization of resource potential, the sphere of food production, and the sphere of food distribution and consumption. A methodological approach to the calculation of the risk of negative fluctuations of food security indicators in the context of estimating the corresponding coefficients of semivariation has been proposed. Strategically important types of agricultural products have been selected for the study, namely grain crops and legumes, sunflower, vegetables, meat and milk. In general, the calculations have shown an increased risk of negative fluctuations in the affordability of domestic food products against the background of intensification of internal and external threats to food security of Ukraine. The integrated risk coefficient for agriculture at large is 14.03 (the risk coefficient of crop production is 15.37 , for animal husbandry 7.04 ).
\end{abstract}

\section{Statement of the problem}

Food security is certainly one of the determining factors in the formation and functioning of the country's national security system. On the one

\section{Keywords}

Food security, food independence, globalization, risks, threats, semi-variation

JEL: Q18 
social growth. On the other hand, it increases the need for professional and high-quality assessment of risks and threats. Instead, identification of risks and threats to food security in a timely manner makes it possible to assess the existing trends of its main indicators and further forecast them. Carrying out of the corresponding studies will provide the opportunity to define trends in the development of key parameters of food security and to establish how the sources of its maintenance change. This outlines the imperative of building a balanced national food security policy to strengthen Ukraine's competitive status as a powerful player on the global stage.

\section{Latest scientific progress and publications review}

The studies of many domestic researchers are devoted to the problems of food security of the country and the identification of risks and threats to its formation. Special attention to this problem is paid in the works of such researchers as O. Gorniak, A. Danylenko, O. Darmograi, G. Kaletnik, V. Kornienko, A. Mostova, O. Nikoliuk, A. Poltorak, S. Revenko, A. Rudych, M. Sychevskyi, A. Skrypnyk, L. Tarasovych, N. Tikhonova, V. Tkachuk, Yu. Kharazishvili, I. Fedulova, V. Chepurko, A. Shevchenko and others. [1; 3; 7-11]. The studies of these researchers form the basis for effective scientific and applied developments in the field of food security. However, modern challenges increase the need for constant monitoring of risks and threats to the formation of food security in the context of globalization.

\section{The purpose of research}

The purpose of the study is to analyze the risks and threats to ensuring food security of Ukraine on the basis of the author's methodology used to calculate the risk of negative fluctuations of the relevant indicators based on the results of the assessment of semi-variation coefficients.

\section{Results of the research}

Based on the systematization of key provisions of a number of laws and regulations and results of scientific research conducted by modern researchers, ensuring food security is understood as the development and implementation of socioeconomic, organizational, legal, scientific-innovative, informational, environmental and other measures aimed at protecting the interests of a person, community, region and state in terms of physical, economic and social accessibility, food safety and quality, food security and food sovereignty.

In a broad sense, food security of a country is an economic category that is always accompanied by threats and risks of losing food independence. Therefore, the analytical study of the current state and, especially, trends in food security of the country involves the use of risk management tools. At the first stage, it is necessary to identify potential food security risks and then quantify and grade them depending on their significance. The risk of food security is associated with the possibility of negative changes in the level of security. The more likely the possibility of adverse changes, the higher the level of risk. The process of identifying food security risks should be based on the results of the analysis of factors that cause the risks.

In the context of the research topic, risk factors are usually considered through the lens of food security threats, which are defined as "any negative changes in external and internal environmental factors that reduce the level of food security" in the draft Law of Ukraine [5].

Given the convergence of our country to the world community, food security should be considered as a priority due to the existence of certain national contradictions. Firstly, it is the instability of the domestic agricultural sector, especially agriculture, despite its indispensable role and a stable position in the structure of national production. Secondly, there are certain special aspects of the functioning of the agri-food market from the standpoint of its economic interpretation. Thirdly, this is the existing (actual) level of food consumption by the population (ratio of needs and opportunities for provision). In this regard, the tasks of the state in terms of food security, especially in the field of public administration policy, is to create favorable conditions for sustainable agricultural development, as well as a balanced market conjuncture (demand and supply of food) against the background of significant fluctuations in the level of profitability in the agri-food sector of the national economy. The generalized content of real and potential threats, as well as tasks in the field of food security is given in Table. 1.

Threats to food security can lead to unfavourable changes in food security indicators of the country. In other words, the process of formation of food security risks can be considered in the following cause-and-effect sequence: threats to food security possible negative change in the food safety indicator risk as the probability of a possible negative change in the indicator. Taking into account this sequence, it is possible to identify three stages of assessing the risk of the country to lose food security, namely: 1) systematization of food security indicators from the standpoint of risk management; 2) identification of all factors/threats that may cause adverse changes in indicators; 3 ) assessment of the possibility/probability of 
TABLE 1 Threats and tasks in the field of food security of Ukraine

\begin{tabular}{|c|c|}
\hline Threats to food security (real and potential) & National tasks in the field of food security \\
\hline $\begin{array}{l}\text { - black economy, inflation and deflation, economic } \\
\text { free fall } \\
\text { - } \text { reduction of employment, illegal migration } \\
\text { - non-compliance with quality and safety standards } \\
\text { critical dependence of the national economy on } \\
\text { external factors and on the conjuncture of foreign } \\
\text { markets } \\
\text { - insufficient organizational and financial support of } \\
\text { public procurement of vital food products and their } \\
\text { inefficient use } \\
\text { reduced access to domestic and export markets or } \\
\text { their segments due to hazardous food products } \\
\text { - irrational use of agricultural land } \\
\text { - anthropogenic load, increasing risks of man-made } \\
\text { and natural emergencies, in particular the presence } \\
\text { of negative social and environmental consequences } \\
\text { of the Chornobyl accident } \\
\text { - insufficient control over the production of } \\
\text { environmentally hazardous technologies, } \\
\text { substances, materials and genetically modified } \\
\text { organisms and their import to Ukraine } \\
\text { - social and cultural issues associated with the } \\
\text { protection of the interests of food consumer groups }\end{array}$ & $\begin{array}{l}\text { - ensuring a high level of protection of human life and health and } \\
\text { protection of consumer interests, elimination of hunger and the } \\
\text { consequences of malnutrition } \\
\text { - ensuring sustainable development of quality and safe food } \\
\text { production to the extent necessary to guarantee food security } \\
\text { - promoting the dynamic development of all areas of the agricultural } \\
\text { sector maintaining a high level of their competitiveness } \\
\text { - ensuring a stable food supply chain for the consumer } \\
\text { - prevention of threats to food security, minimization of their } \\
\text { negative consequences } \\
\text { - maintenance and conservation of biodiversity, genetic resources } \\
\text { and ecosystem services } \\
\text { - ensuring high standards of management and care rules in animal } \\
\text { husbandry } \\
\text { - ensuring the rational use of natural resources } \\
\text { - increasing the resilience of agriculture and food systems to the } \\
\text { effects of climate change } \\
\text { - improving the system of state regulation and management in the } \\
\text { field of food security, identification of responsible institutions and } \\
\text { agencies dealing with food security, the legal basis of their work } \\
\text { and levels of cooperation and coordination } \\
\text { - creation of comprehensive and rational systems for food quality } \\
\text { control that reduce the risk of foodborne diseases using the } \\
\text { mechanisms of monitoring and surveillance to ensure food } \\
\text { security in the food chain } \\
\text { - identification of key indicators of the monitoring system of food } \\
\text { safety to assess trends in food chains } \\
\text { - udaptation of domestic legislation in the field of food security } \\
\text { - ror the benefit of Ukraine } \\
\text { raising consumer awareness of food security issues }\end{array}$ \\
\hline
\end{tabular}

Source: generalized by the authors based on the studied sources [1-11]

negative changes in food safety indicators due to each of the identified factors/threats.

Risk is probabilistic in nature, so it can be argued that it does not always lead to negative changes. Therefore, quantitative assessment of food security risks involves the numerical measurement of the possibility that a threat is realized and will lead to a real deterioration of food security indicators. In addition, it is important to determine how strong and significant the negative change can be, because even a high probability of a negative scenario does not always mean that the realization of the threat will lead to catastrophic consequences. Instead, the most serious risks, even with a low probability of occurrence, should be reduced as they can lead to a complete loss of food independence.

In most literature sources, depending on the area of origin (within or outside the country), food security threats are classified into internal and external. Internal threats are usually more manageable and can be addressed if detected in a timely manner. Instead, external threats are largely unaffected by the country and need to be taken into account in food security strategies. Within each group of food security indicators, there are both internal and external threats.

In terms of the formation of resource potential, the following indicators can be distinguished: labour, land, and material resources. Particularly, these are intensification of the policy of other countries towards attracting workforce from Ukraine, climate change and reduction of agricultural land area, low level of training, labor migration, depreciation of the national currency and increase in the value of credit funds, reduction of domestic production of machinery, raw materials, etc. It is necessary to distinguish production volumes and efficiency in the field of food production (improvement of market conjuncture of product types that are not strategically important for food security; change of production structure of agricultural holdings towards increase of product types that are not strategically important for food security; unfavourable natural and climatic changes; reduction in yields; reduction in the efficiency of agricultural production and/or increase in the attractiveness of business in other areas; deagrarization of rural areas, etc.). As for the distribution and consumption of food products, the growth of exports and erosion of purchasing 
power should be noted (significant improvement in the export of food products, improving conjuncture in the world markets for agricultural products; inflation; higher efficiency of exports compared to domestic sales; increased costs for non-food goods and services (tariffs), etc.).

To determine the significance of the impact of each of the identified threats, it is expedient to use the sensitivity analysis, which makes it possible to determine how much (in percentage terms) the performance indicator will increase (in this case, food security indicator), if the factor indicator (i.e. indicator that quantifies the threat) is increased by $1 \%$. Coefficients of elasticity can be calculated on the basis of regression analysis. In the second case, it is necessary to construct regression equations that reflect the relationship between the factorial and the effective feature.

Since most threats cannot be estimated by calculation, the study only examined the sensitivity of food production in terms of food products as a determinant of food security. Accordingly, the factors of production include labour, land and material resources. Strategically important types of agricultural products have been selected for the study, namely grain crops and legumes, sunflower, vegetables, meat and milk.

The regression analysis showed that there is no significant correlation between the following TABLE 2 Coefficients of elasticity of production output for

\begin{tabular}{|c|c|c|c|c|}
\hline \multirow[b]{2}{*}{ Factor } & \multicolumn{4}{|c|}{ Type of agricultural products } \\
\hline & $\begin{array}{c}\text { grain crops and } \\
\text { legumes }\end{array}$ & sunflower seeds & $\begin{array}{l}\text { meat in slaughter } \\
\text { weight }\end{array}$ & milk \\
\hline Sown area of an agricultural crop & 0.81 & 0.86 & - & - \\
\hline Cattle population* & - & - & 0.90 & - \\
\hline Pig population & - & - & 1.08 & - \\
\hline Cow population & - & - & - & 1.02 \\
\hline
\end{tabular}

Note: ${ }^{*}$ - excluding cow population.

Source: calculated by authors

the degree of random fluctuations in indicators that pose an increased threat to the country's food security. In order to eliminate the problem of subjective judgments about risk, it is better to use formalized methods of mathematical statistics in the process of risk assessment. In particular, Nikoliuk O. propose to use coefficients of variations or semi-variations as indicators of the risk level [4]. The coefficient of variation reflects the general degree of variability of the indicator, while the coefficient of semi-variation reflects the degree of variation only in the direction unfavourable for the country. Coefficients of semi-variation have been used in the study, since favourable fluctuations in food security indicators are not associated with the threat to lose food independence. In that case, the risk indicators will be calculated at two levels: partial risk indicators (coefficients of semi- indicators:

1) the volumes of produced grain and legumes do not correlate with the number of people employed in agriculture and the index of sown area;

2) the volume of produced sunflower seeds does not depend on the number of people employed in agriculture;

3) the volume of produced vegetables does not depend on any of the selected factors.

The results of the study indicate that among the selected factors only sown area affects the volume of production of grain crops and legumes; an increase of sown area by $1 \%$ will increase production by $0.81 \%$. The area of sunflower has a slightly greater impact on the increase in production. Pig and cattle population (excluding cow population) have a significant impact on the production of meat in slaughter weight; a $1 \%$ change in population will increase production by 0.9 and $1.08 \%$, respectively. Similarly, a $1 \%$ growth in cow population will increase milk production by about $1.02 \%$. The obtained results give grounds to argue that random fluctuations of these factors have a significant impact on the risks of losing food independence of the country. Therefore, their value when assessing the relevant risks (Table 2).

The next step in risk assessment is to quantify main types of agricultural products per 1 person, $\%$ must be weighed by a coefficient higher than 1 variation) weighted by their respective weight coefficients; an integrated indicator of food security risk, which has to be scaled. Coefficients of semi-variation are calculated according to the method presented in [4].

In addition to the above-mentioned livestock population and sown areas of agricultural crops, the risk assessment takes into account such sources of risk as yielding ability and productivity of farm animals, average annual temperature and average annual rainfall, as well as the ratio of the average annual wage index to the consumer price index (indicator of threat to affordability of food products).

However, Chepurko V. points out that some indicators are characterized by a clear tendency to change over time [10]. First of all, these are indicators of crop productivity (tendency to 
increase due to scientific and technical progress as well as introduction of new technologies in agriculture) and livestock population, which tends to decrease steadily. That is why the researcher proposes to calculate risk coefficients not on the basis of actual values of risk indicators, but their deviations from the trend. As previously mentioned, the risk is associated with random fluctuations in the risk indicator, in other words, with random deviations from its expected levels. The coefficient of semi-variation is based on fluctuations around the mean value, while in our opinion, the risk is associated with deviations from the expected value, i.e. the trend one.

Thus, on the basis of the time series of indicators (with a depth of 10 years) of yielding ability and livestock population, the trends of the levels are constructed and the coefficients of semi-variation are calculated. After that, the absolute deviations of the actual values of indicators from the trend are determined for each year. And risk coefficients are calculated on the basis of time series of deviations from the trend of the levels of yielding ability and productivity of farm animals. There is a special feature of calculating the risk coefficients for these indicators. The risk coefficient of negative deviations of yielding ability and livestock population is calculated according to the formula of the semi-variation coefficient, but the denominator calculates the mean value according to actual yield and livestock population, not the mean value of deviation. Coefficients of semivariation for other risk indicators (sown area, livestock population and the ratio of wage and inflation indices) are calculated on the basis of their actual values.

Taking into account the significance of food security risks, their levels will be determined according to the formula:

$$
r_{i}=\omega_{i} \cdot S S V_{i}
$$

where $r_{i}-$ coefficient of risk of negative fluctuations in $i$-indicator of food security; $\omega_{i}$ - coefficient of significance of the risk of negative fluctuations in $i$-indicator of food security; $S S V$ - semi-variation coefficient of $i$-indicator of food security.

For indicators with coefficients of elasticity from 0.1 to 1 , the weight coefficients are set at 1.2, while for coefficients of elasticity above 1 they are set at 2 - 1.5. For other risk indicators, the coefficients of elasticity equal 1 . The risks have been calculated for grain crops, legumes, sunflower, vegetables, fruit and berries. Table 3 shows that the indicator of the ratio of the average monthly wage index to the consumer price index is the most unstable in its dynamics. In particular, the share of scatter of this food security indicator in the negative direction from its mean value is $45.26 \%$. This indicates an increased risk of negative fluctuations in food affordability in Ukraine.

TABLE 3 Coefficients of partial and integrated coefficients of risks that may lead to the loss of food security

\begin{tabular}{|c|c|c|c|}
\hline Indicator of risk that may lead to the loss of food security & $\begin{array}{l}\text { Weight } \\
\text { coefficient }\end{array}$ & $\begin{array}{l}\text { Coefficient of } \\
\text { semi-variation }\end{array}$ & $\begin{array}{l}\text { Weighted risk } \\
\text { coefficient }\end{array}$ \\
\hline Sown area of grain crops and legumes & 1.2 & 2.75 & 3.30 \\
\hline Sown area of sunflower & 1.2 & 16.23 & 19.48 \\
\hline Sown area of vegetables & 1.0 & 3.60 & 3.60 \\
\hline Sown area of fruit and berries & 1.0 & 8.52 & 8.52 \\
\hline Yielding ability of grain crops and legumes & 1.0 & 12.96 & 12.96 \\
\hline Yielding ability of sunflower & 1.0 & 11.54 & 11.54 \\
\hline Yielding ability of vegetables & 1.0 & 17.37 & 17.37 \\
\hline Yielding ability of fruit and berries & 1.0 & 46.18 & 46.18 \\
\hline Cattle population & 1.2 & 5.42 & 6.51 \\
\hline Pig population & 1.5 & 4.20 & 6.29 \\
\hline Cow population & 1.5 & 8.40 & 12.60 \\
\hline Average annual milk yield from 1 cow & 1.0 & 6.15 & 6.15 \\
\hline Average daily increment of cattle on feed, fattening and rearing & 1.0 & 4.79 & 4.79 \\
\hline Average daily increment of pigs on feed and rearing & 1.0 & 5.89 & 5.89 \\
\hline The ratio of the average annual wage index to the consumer price index & 1.0 & 45.26 & 45.26 \\
\hline \multicolumn{3}{|c|}{ Integrated risk coefficient in the context of plant products } & 15.37 \\
\hline \multicolumn{3}{|c|}{ Integrated risk coefficient in the context of livestock products } & 7.04 \\
\hline \multicolumn{3}{|c|}{ Integrated risk coefficient in the context of agriculture at large } & 14.03 \\
\hline
\end{tabular}

Source: authors' research 
The risk of adverse deviations in the yielding ability of fruit and berries is similarly high. They are also characterized by a relatively high risk of reducing the area of plantations. In general, sunflower is characterized by the most significant risks of reducing the sown area. According to the results of the analysis of the risk of cultivating agricultural crops, the main source of risk of reducing their production is accidental adverse fluctuations in yields, rather than the sown area. Particularly, the average value of weighted coefficients of semi-variation of the yield level for the studied crops is $22.01 \%$, which is by 2.5 times higher than the average coefficient of semivariation of the sown area.

As for the livestock production, it is characterized by a much lower level of risk. It should be emphasized that risk is always associated with random fluctuations, while a steady upward or downward trend is not a risk. On the contrary, the existence of a steady downward trend in livestock population is a manifestation of low risk level. However, it indicates a high probability of decline in livestock production due to fairly predicted and determined (rather than random) factors. Similarly, the risk of reduced productivity of farm animals is low. In general, the highest risk in the livestock sector is typical for milk production due to the relatively high weighted coefficient of semi-variation of cow population. Overall, comparing the levels of risk in crop production and animal husbandry, it can be argued that the risks in animal husbandry are much lower than in crop production. One of the main reasons for this is the variability in yields, which, among other things, is associated with the climate change.

\section{Conclusions}

Comparing the determined levels of risk of crop production and animal husbandry, it has been concluded that the risks in animal husbandry are much lower than in crop production. The integrated risk coefficient in crop production is 15.37, in animal husbandry 7.04. The weighted risk coefficient for agriculture at large is 14.03 . The high level of risk of losing food independence in the field of crop production indicates the need for active actions that have to be taken by the state in this direction. The declining trend in livestock population is a manifestation of low risk level. However, this confirms the high probability of decline in livestock production due to fairly predicted and determined factors. The coefficient of semi-variation in calculating the ratio of the average annual wage index to the consumer price index is $45.26 \%$; it indicates an increased risk of negative fluctuations in food affordability in Ukraine.

\section{References}

[1] Kravchuk N, Tarasovych L, Yaremova M 2017 Development of the socially-oriented economy in Ukraine: prereguisites and strategic forecasting Baltic Journal of Economic Studies 3(2) 66-72 doi: https://doi.org/10.30525/2256-0742/2017-3-2-66-72

[2] Ministerstvo ekonomichnoho rozvytku i torhivli Ukrainy 2013 Pro zatverdzhennia Metodychnykh rekomendatsii shchodo rozrakhunku rivnia ekonomichnoi bezpeky Ukrainy [About the statement of Methodical recommendations concerning calculation of level of economic safety of Ukraine] E-source: http://cct.com.ua/2013/29.10.2013_1277.htm

[3] Mostova A D 2019 Instytutsiine zabezpe-chennia prodovolchoi bezpeky derzhavy [Institutional support of food security of the state] Problemyekonomiky 3 68-76 doi:https://doi.org/10.32983/22220712-2019-3-68-76 (in Ukrainian)

[4] Nikoliuk O M 2016 Upravlinnia konkurentospromozhnistiu silskohospo-darskoho pidpryiemstva: teoretyko-metodolohichni osnovy: monohrafiia Zhytomyr: ZhNAEU 314 (in Ukrainian)

[5] Pro prodovolchu bezpeku Ukrainy [On food security of Ukraine] 4227-IV (2011) (in Ukrainian)

[6] Prodovolcha bezpeka: sutnist, stan ta osoblyvosti zabezpechennia: monohrafiia / kerivnyk avt. kol. prof. I. V. Fedulova. K.: Kondor-Vydavnytstvo 2013468 (in Ukrainian)

[7] Revenko S O 2013 Metodolohichni pidkhody do otsinky rivnia zahroz prodovolchii bezpetsi Ahroinkom 10-12 61-64 (in Ukrainian)

[8] Tkachuk V, Yaremova M, Tarasovych L 2017 Rroviding the food security of Ukraine Suchasni pytannia ekonomiky i prava: Zb. nauk. 1-2(5, 6) 173-8 (in Ukrainian)

[9] Fedulova I V 2014 Doslidzhennia prodo-volchoi bezpeky: pryntsypy i pidkhody shchodo otsinky Stratehiia ekonomichnoho rozvytku Ukrainy 34 40-6 (in Ukrainian)

[10] Chepurko V V 2000 Ekonomycheskyi rysk ahrarnoho proyzvodstva: teoryia, metody otsenky, upravlenye Symf.: Tavryia 308 (in Ukrainian)

[11] Tikhonova N O 2014 Prodovolcha bezpeka derzhavy: zahrozy ta perspektyvy Naukovyi visnyk Khersonskoho derzhavnoho universytetu. Ser. Ekonomichni nauky 8(4) 46-9 (in Ukrainian) 